\title{
Understanding the Meaning of Speaking by Conversational Implicature
}

\author{
Vidya Mandarani \\ Fakultas Keguruan dan Ilmu Pendidikan \\ Universitas Muhammadiyah Sidoarjo \\ Sidoarjo, Indonesia \\ vmandarani@umsida.ac.id
}

\begin{abstract}
Conversational implicature is related to the knowledge of what the speaker and the listener about something that is more focus to the understanding of the utterances said. Grice recommended that conversation will be understood if it is meet four maxims, so that the cooperative principle will be reached in conversation. In conversation people can use maxims of quality, quantity, relation and manner. Here the writers analyzed conversational implicature used by health analysts' students of UniversitasMuhammadiyahSidoarjoin their English speaking. This study used qualitative approach with descriptive method. The writer recorded the students' speaking, transcribed, and analyzed conversational implicatureof health analyst students of UniversitasMuhammadiyahSidoarjo. The result showed the students use conversational implicature in their speaking. The maximsuse isquality, quality relation and manner. This study is important to give one of strategies to convey the meaning from the speaker to the hearer in delivering the message of conversation.
\end{abstract}

Keywords-conversational implicature; maxims; cooperative principle

\section{INTRODUCTION}

Speaking is the main point in learning English desperately needs special attention for countries that have English as a second language. Mastery of language is not only grammar but also on the delivery of the meaning of the conversation. When we have conversations in English sometimes there is a meaning to be conveyed by a speaker who must be understood by the listener, even though the language is not directly stated.Pragmatics is essentially about the users of language in a real-life situation, and about the conditions that enable those users to employ linguistic techniques and materials as effective and appropriate as possible [1].

Indonesian who speak English only in certain situations must be able to form the meaning in a speech so that can be understood by the listener. Conversational implicature is related to the understanding of the conversation. The understandingis related to the terms imply, suggest, and mean [2]. Implicature becomes the essentialparts in pragmatics [3]. The focus is in the relation between what people tell and what they actually mean. Grice created four maxims of conversation which describe what listeners assume speech will be understood. The cooperative principle is the term of four maxims which possibly effective and cooperative in conversation. Grice suggested four maxims expected in conversation [4]. The first is quality maxims, the speaker deliver the truth or provable by enough evidence in the conversation. The second is quantity maxims; the speaker is as very informative in delivering the message. The third is relation maxims; the answer is really relevant to the question in conversation. The fourth is manner maxims, the speaker's did not do some ambiguity, but directlydiscuss about the topic.

In recent years not only conversational, but also conventional implicaturehas gotten big attention in the pragmatics and semantics. There are now two competing conceptions of conventional implicature, but this fact is not always recognized [5]. The studybetween the Language-based and Rationality-based is how Relevance implicatures are computed and found support for the Language-based account but not the Rationality-based account. On the Language-based account, children were predicted to perform better on computing non-linguistic inferences than Relevance implicatures that are parallel in nature because in order to compute Relevance implicatures children need to master additional linguistic prerequisites. On the Rationality-based account, children were not predicted to perform better on computing non-linguistic inferences than Relevance implicatures. It is found that children performed significantly better on computing non-linguistic inferences than Relevance implicatures, which provided evidence for the Language-based account [6]. It seems that language, and specifically, about the role irrelevant utterances in discourse, becomes the main acquisition challenge with respect to Relevance implicatures. This study focuses on implicature of how students who are not from English majors use English in their conversation. This study is conducted to know the students' speaking used four maxims in conversation and implied the meaning.

\section{METHODS}

The method of the research is descriptive qualitative research. Descriptive qualitative research is research that conducted to understand the phenomenon of what isrelated to the research subject, life, perception, motivation, and action. By using the descriptive qualitative methods offer the opportunity to explore the subject of this study in detail related to the speaking analysis of the health analysts' students at Universitas Muhammadiyah Sidoarjo. The subject consists of 29 students. The technique of collecting data used the documentation technique. The utterances contain the maxims in conversational implicature of the students' speaking. This study was conducted through several steps of collecting the data; the writer recorded 
the students' speaking, transcribed, and analyzed conversational implicature of health analyst students of Universitas Muhammadiyah Sidoarjo. The utterances is contained the maxims quality, quantity, relation and manner in conversational implicature.

\section{FINDINGS AND DISCUSSION}

This findings will be shown the maxims use by the students to convey the meaning by applying the maxims, those are quality, quantity, relation and manner.

TABLE 1. MAXIMS USED BY THE STUDENTS

\begin{tabular}{|c|c|c|}
\hline Conversation & Categories & Meaning \\
\hline $\begin{aligned} \mathrm{S}_{1} \text { : Now we will give you the } \\
\text { process of taking blood. } \\
\text { First, put the tourniquets } \\
\text { above arms. Then, clean } \\
\text { the arms with cotton } \\
\text { alcohol. Then insert the } \\
\text { niddle to the arm. } \\
\mathrm{S}_{2} \text { : After that removing the } \\
\text { tourniquets, give the arms } \\
\text { cotton alcohol. Put the } \\
\text { blood in the sample } \\
\text { bottle. }\end{aligned}$ & $\begin{array}{l}\text { Maxims of } \\
\text { quality }\end{array}$ & $\begin{array}{l}\text { The student explains the } \\
\text { process of taking blood by } \\
\text { using maxims of quality. It } \\
\text { can be seen that the first } \\
\text { student explain what she is } \\
\text { going to do, then continue to } \\
\text { describe one by one the truth } \\
\text { process till the blood put into } \\
\text { the sample bottle. }\end{array}$ \\
\hline $\begin{array}{l}\mathrm{S}_{3}: \text { Press two paper roll to be } \\
\text { flat, like this. Twist the yarn } \\
\text { around the paper roll. } \\
\mathrm{S}_{4}: \text { Cut the yarn. Then enter } \\
\text { the rest of the yarn in the } \\
\text { scroll, like this. }\end{array}$ & $\begin{array}{l}\text { Maxims of } \\
\text { quantity }\end{array}$ & $\begin{array}{l}\text { The student explain about the } \\
\text { first step then continued by } \\
\text { second student very clear } \\
\text { explain the next step. }\end{array}$ \\
\hline $\begin{array}{l}\mathrm{S}_{5}: \text { I want to tell you about } \\
\text { how to make miniature of } \\
\text { helicopter. The first prepare } \\
\text { the tool and material } \\
\mathrm{S}_{6} \text { : The tool and material are } \\
\text { scissor, straw, milk bottle, } \\
\text { and table tennis ball. } \\
\mathrm{S} 5 \text { : Next, lets we make it }\end{array}$ & $\begin{array}{l}\text { Maxims of } \\
\text { relation }\end{array}$ & $\begin{array}{l}\text { The student explains the } \\
\text { purpose of speaking that is } \\
\text { the students want to make } \\
\text { miniature of helicopter. Then } \\
\text { it is much related after tells } \\
\text { the purpose, } \mathrm{S}_{6} \text { explains the } \\
\text { tool and material. }\end{array}$ \\
\hline $\begin{array}{l}\text { S7 : The first pour glue into } \\
\text { the bowl } \\
\text { S8 : Then give water and stir } \\
\text { it. Please do not give too } \\
\text { much water. } \\
\text { S7 : After that we pour liquid } \\
\text { soap, and keep stir it again } \\
\text { S8 : The we give food } \\
\text { coloring and stir it }\end{array}$ & $\begin{array}{l}\text { Maxims of } \\
\text { manner }\end{array}$ & $\begin{array}{l}\text { S8 avoid ambiguity by giving } \\
\text { the detail information about } \\
\text { the water with the utterance } \\
\text { "Please do not give too much } \\
\text { water". }\end{array}$ \\
\hline
\end{tabular}

Based on the findings above, the discussion is going to the first, maxims of quality. The students use maxims of quality because the explanation is true related to the real process of taking the blood. The utterance is very natural to express the process of taking blood. The students try to make the contribution is true and explain the process by telling the truth the process with the simple way. The second, the student also performs the speaking use maxims of quantity. Maxims of quantity means that the students the speaker is as informative as required. The student's explanation about how to make pompom rug is really informative. So that the explanation of how to makepompom rug is very good and understandable. The third is maxims of relation means that the response is relevant to topic of discussion. The students present how to make the miniature of helicopter, then directly explain the ingredient use.At first the students use maxims of relation in their speaking, because after explain the tool and material, the student explain the process of making miniature of helicopter.The fourth is maxim of manner;the students' avoids ambiguity or obscurity in their speaking. The explanation is direct and straightforward to the purpose. The students want to explain how to make slime. It shows that the speaker utterance is direct to the purpose of avoiding the ambiguity. The focus is in the amount of the water. All the data can be drawn like the figure below.

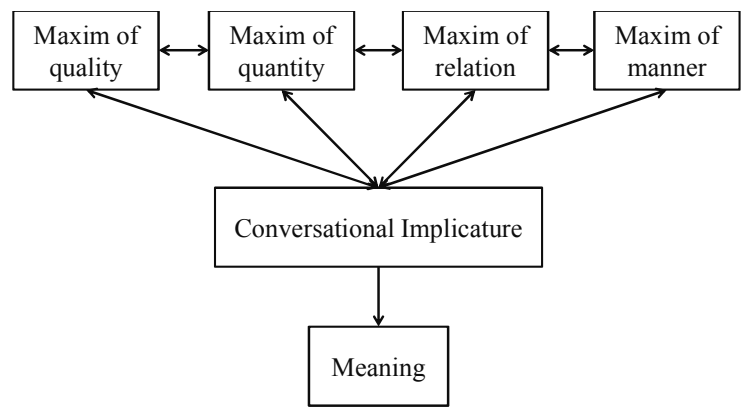

Fig. 1. The conversational implicature of maxims

This figure showed the connection between every maxim to reach the conversational implicature and convey the meaning of the conversation. The way the students express their utterance from the four maxims, shows that there is a relationship between one maxims with the other maxim. If we see the example shown in maxim of quality, it can be seen that $\mathrm{S} 1$ and $\mathrm{S} 2$ also use maxim of quantity, relation and manner. It is because $\mathrm{S} 1$ also gives the information very clear, really relevant to the topic and also convey the meaning directly to the focus of the taking blood process. The same happen if we see the example of maxims of quantity, S3 dan S4 also use maxims of quality, relation and manner. It is because the speaker tells the truth, relevant, brief and clear.

Maxims in conversational implicature salso can be applied to all languages of the world. The speech can be organized and has implicatures. The theory can be used to idiolects of nonstandard Arabic [7] so that it is not only if the speaker used English in communication. In addition English is not the first language in Indonesia. The students sometimes used the conversational implicature to clarify the meaning to the hearer. The strategies really need to keep the understanding and all the language used implicature has the same significance to reach the meaning. In line with this statement, speaker meaning may arise 
as what is said as a goal of maxim fulfillment and implicature as a consequence of flouting maxim [8]. The maxim can create the meaning clearer and understandable. The violation of maxims sometimes happened to the participant of speaking that is still having the problem in using the language.

The speech can arise the ambiguity if it is related to the culture of the source language. Levinsonian maxims of quantity and informativeness can propose that constructions potentially ambiguous between the two context [9].Grice's influential contribution is the cooperative principle in the form of maxims and implicatures [10]. Related to this study the quality, quantity, relation and manner maxims lead the formulation of conversational implicature. The purpose of the formulation is to understand the meaning of the conversation. The students used all the maxims in their conversation so that the untruthfulness, unclear, and ambiguity did not happen along the delivering the idea.

\section{CONCLUSION}

We can see that the speaking used the strategies to convey the meaning. The data shows that the use of conversational implicature makes the conversation clearer to be understood. From the quality, quantity, relation and manner maxims the students use the cooperative principle of maximsto reach the understandable meaning from the speaker to the hearer in the conversation. Hopefully this research can give contribution to the speaking field related to the delivering clear message in communication used maxims.

\section{ACKNOWLEDGEMENT}

Thanks to Universitas Muhammadiyah Sidoarjo for supporting this research paper.

\section{REFERENCES}

[1] Mey J L, Pragmatics An Introduction. USA: Blackwell Publisher Inc Cambridge, Massachusetts 02142, 2004.

[2] Grice P, Studies in the Way of Word. Cambridge: Harvard University Press, 1989.

[3] Levinson S C, Pragmatics, London: Cambridge University Press, 1983.

[4] Yule G, Pragmatics, Oxford: Oxford University Press, 1996.

[5] Salmon, W, Conventional implicature, presupposition, and the meaning of must, 2011, Journal of Pragmatic, Vol 43, pp 3416-343

[6] Verbuk, A., Shultz, T, Acquisition of Relevance implicatures: A case against a Rationality-based account of conversational implicatures, 2010, Journal of pragmatics, vol 42 pp 2297-2313

[7] Alduais A M S, "Conversational Implicature (Flouting the Maxims) : Applying Conversational maxims on examples Taken from Non-Standar Arabic Language, Yememi Dialect and Idiolect Spoken at IBB City," 2012, Journal of Sociological Research, vol 3, pp. 376-387.

[8] Dynel, M, But seriously :on conversational humour and (un) truthfulness, 2017, Lingua, vol 197, pp 83-102.

[9] Vallejo D, R, Actuality effects as conversational implicatures, 2017, Journal of Pragmatics, Vol 112, pp 44-67.

[10] Ephratt, M, "We try harder" - Silence and Grice's cooperative principle, maxims and implicatures, 2012, Language and communication, Vol 32, pp $62-79$ 